Vol. 17 No. 34 Juli - Desember 2018

\title{
IMPORTANCE PERFORMANCE ANALYSIS DALAM KASUS KEPUASAN KONSUMEN USAHA LAUNDRY
}

\author{
Restu Khaliq \\ UIN Antasari Banjarmasin
}

\begin{abstract}
Importance Performance Analysis (IPA) is one method measuring the gap of service quality attributes according to the consumer's perspective. The application of this method is important in the field of business services such as laundry because some people today are often unable to do daily routine work such as washing dirty clothes. Using laundry services is one solution. This study aims to assess service quality attributes which are divided into two sub-variables (functional quality and technical quality) through Importance Performance Analysis (IPA) in XYZ laundry service businesses. The number of respondents in this study was 72 people. The research questionnaire was distributed to all XYZ laundry customers from July to September 2018. The results of this study indicate that $X Y Z$ luandry business is recommended to prioritize service on good delivery of consumer goods, cut down on waiting time for service work, improve employee appearance and try to show business to help.
\end{abstract}

Keywords: Importance, Performance, Kepuasan Konsumen, IPA.

\section{Pendahuluan}

Pola hidup masyarakat yang semakin padat dengan aktifitas keseharian merupakan fenomena yang umum saat ini. Padatnya aktifitas membuat rutinitas sehari-hari seseorang terkadang tidak bisa dikerjakan sehingga menuntut jalan keluar. Pada sebagian orang salah satu rutinitas yang sekarang sering kali tidak dapat dikerjakan adalah 
mencuci pakaian kotor. Menggunakan jasa laundry adalah salah satu solusinya.

Salah satu unit usaha yang bergerak dalam bidang laundry di Kota Banjarmasin adalah Jasa Laundry XYZ. Jasa luandry ini menawarkan berbagai macam jasa laundry di antaranya; 1) Premium laundry, 2) Cuci kering, 3) Cuci kering setrika dan 4) Dry clean karpet. Dari sudut pandang konsumen, besar harapan untuk mendapatkan layanan yang bagus. Tuntutan akan kepuasan konsumen adalah hal yang lumrah dalam dunia bisnis saat ini terutama usaha yang bergerak dalam bidang jasa. Jika kepuasan konsumen tidak bisa diwujudkan maka yang muncul bisa jadi sebaliknya yaitu ketidakpuasan konsumen.

Ketidakpuasan konsumen akan terjadi jika mutu produk/jasa jelek, harga yang mahal, pengantaran yang lambat serta pelayanan yang seenaknya. Sebaliknya, kepuasan konsumen akan tercapai jika produk bermutu baik, harga lebih murah, waktu pengantaran dan penyerahan yang cepat, pelayanannya yang baik. 59 Untuk mengukur kepuasan konsumen dalam berbagai literatur yang sering didiskusikan adalah dengan melibatkan konsep service quality yang terbagi menjadi technical and functional quality model. ${ }^{60}$ Melalui atribut technical and functional quality ini akan diketahui atribut-atribut mana saja yang membuat konsumen merasa puas dan atribut-atribut mana saja yang masih belum bisa memenuhi harapan konsumen jasa Laundry XYZa dengan analisis menggunakan metode-metode tertentu.

Importance Performance Analysis (IPA) adalah salah satu metode untuk mengukur gap atribut-atribut service quality menurut sudut

59 E. M. Doelhadi dan Agus Subekti, "Mengukur Tingkat Kepuasan Pelanggan: Perspektif Psikologi Konsumen," Fakultas Psikologi Universitas Airlangga 8, no. 1 (2006).

60 Christian Grönroos, "A Service Quality Model and Its Marketing Implications," European Journal of marketing 18, no. 4 (1984): 36-44. 
pandang konsumen. Metode ini memiliki beberapa kelebihan bila dibandingan dengan metode lain diantaranya; 1) Mudah untuk mengetahui atribut jasa yang perlu ditingkatkan ataupun dikurangi untuk menjaga kepuasan konsumen, 2) hasil yang relatif mudah diinterpretasikan, 3) berbiaya rendah.

Salah satu metode yang dapat digunakan adalah Importance Performance Analysis (IPA) karena memiliki beberapa kelebihan dibandingkan dengan metode lain. Kelebihan tersebut antara lain dapat menunjukkan atribut produk/jasa yang perlu ditingkatkan ataupun dikurangi untuk menjaga kepuasan konsumen, hasilnya relatif mudah diinterpretasikan, skalanya relatif mudah dimengerti, dan membutuhkan biaya yang rendah.

Semua penjelasan di atas menginspirasi peneliti untuk melakukan analisis kepuasan konsumen dengan mengukur service quality (technical and functional quality model) layanan Laundry XYZ menggunakan metode Importance Performance Analysis (IPA).

\section{Kajian Teori}

A. Jasa

Aktivitas, manfaat, atau kepuasan yang ditawarkan untuk dijual adalah pengertian jasa menurut Tjiptono. ${ }^{61}$ Jasa adalah aktivitas yang ditawarkan sesorang kepada orang lain, sesuatu yang ditawarkan tersebut pada dasarnya tidak berwujud dan tindakan tersebut tidak berakibat pada kepemilikan atas sesuatu. ${ }^{62}$ Sementara itu Payne menjelaskan bahwa jasa merupakan aktivitas interaksi dengan konsumen atau dengan barang milik konsumen dimana aktivitas

${ }^{61}$ F. Tjiptono dan C. Gregorius, "Service Quality \& Satisfaction, Yogyakarta: Penerbit ANDI," Edisi III, 2011.

62 Philip Kotler, Manajemen Pemasaran. Edisi IX (terjemahan). Jilid II (Jakarta:

Penerbit Erlangga, 1997). 
tersebut dan tidak berdampak pada pengalihan kepemilikan serta perubahan kondisi tidak berkaitan dengan fisik produk. ${ }^{63}$ Contoh dari jasa yang dijual adalah jasa salon kecantikan, jasa pusat kebugaran (fitness), jasa servis kendaraan/motor dan jasa cuci pakaian (laundry).

Suntoyo menjelaskan bahwa jasa memiliki beberapa karakterisik primer, karakteristik inilah yang membedakannya dengan barang ${ }^{64}$. Karakteristik jasa tersebut adalah:65

1. Tidak berwujud

2. Tidak dapat dipisahkan

3. Heterogenitas

4. Cepat hilang

5. Permintaan fluktuatif

\section{B. Service Quality}

Gronroos dalam Fandy Tjiptono, menjelaskan bahwa persepsi pelanggan konsumen terhadap service quality suatu jasa terdiri atas dua dimensi primer yaitu66:

1. Funtional quality (process-related dimension). Dimensi ini erat berkaitan dengan kualitas "bagaimana" jasa disampaikan seperti perilaku staf, kontak konsumen dan kecepatan layanan, perhatian pribadi, dan pemahaman kebutuhan konsumen.

2. Technical quality (outcome dimension). Dimensi ini berkaitan dengan kualitas output jasa yang dipersepsikan konsumen meliputi fasilitas fisik, perlengkapan, peralatan yang digunakannya (teknologi), dan keakuratan janji pelayanan.

63 Adrian Payne dan Adrian Payne, The essence of services marketing (USA: Prentice Hall, 1993).

64 Danang Sunyoto, "Dasar-dasar manajemen pemasaran," Yogyakarta: Caps, 2012. 65 Ibid

66 Tjiptono dan Gregorius, "Service Quality \& Satisfaction, Yogyakarta." 
Baker dan Lamb meyarankan untuk mendapatkan gambaran yang lebih baik menilai service quality harus mencakup kedua komponen ini. 67

\section{Kepuasan Konsumen}

Menurut Wijaya kepuasan konsumen adalah sesuatu yang diputuskan oleh konsumen berdasarkan pengalaman aktual konsumen terhadap jasa diterima dibandingankan ekspektasi konsumen. ${ }^{68}$ Hal ini senada dengan yang disampaikan oleh Parasuraman, et al. yang menjelaskan bahwa ada dua faktor primer utama yang mempengaruhi service quality. Dua faktor tersebut adalah 69 :

1. Jasa yang diharapkan (expected service)

2. Jasa yang dipersepsikan (perceived service).

Evaluasi pascakonsumsi terhadap suatu alternatif (jasa) yang dipilih setidaknya memenuhi atau melebihi harapan itulah yang didefinisikan sebagai kepuasan. ${ }^{70}$

\section{Importance Performance Analysis}

Martilla dan James adalah orang yang memperkenalkan metode importance performance analysis. Model ini dikenal dengan "quadrant analysis" yang menilai tingkat kepentingan dan menilai kinerja. ${ }^{71}$

67 Julie Baker dan Charles W. Lamb, "Measuring Architectural Design Service Quality," Journal of Professional Services Marketing 10, no. 1 (1994): 89-106.

68 Tony Wijaya, "Manajemen kualitas jasa," Jakarta: PT. Indeks, 2011.

69 Anantharanthan Parasuraman, Valarie A. Zeithaml, dan Leonard L. Berry, "A conceptual model of service quality and its implications for future research," the Journal of Marketing 49, no. 4 (1985): 41-50.

70 Sunyoto, "Dasar-dasar manajemen pemasaran." Op.Cit

71 John A. Martilla dan John C. James, "Importance-performance analysis," The journal of marketing, 1977, 77-79. 
Disebut sebagai "quadrant analysis" karena hasil penilaian yang dilakukan dibagi menjadi 4 kuadran seperti terlihat pada gambar

\begin{tabular}{|c|c|c|}
\hline \multirow{3}{*}{$\begin{array}{c}\text { Sangat Penting } \\
\text { Harapan/ } \\
\text { Kepentingan }\end{array}$} & A. Concentrate Her & B. Keep Up The Good Work \\
\hline & & \\
\hline & C. Low Priority & D. Possible Overkill \\
\hline \multicolumn{3}{|l|}{ Kurang Penting } \\
\hline
\end{tabular}

Masing-masing kuadran memiliki makna yang berbeda-beda. Gamble dan Gambel menjelaskan makna masing-masing kuadran sebagai berikut ${ }^{72}$ :

\section{Kuadran A - Prioritas Utama (Concentrate Here)}

Faktor-faktor yang terletak pada kuadran ini dikategorikan sebagai faktor yang sangat penting jika dibandingkan dengan faktor-faktor lain yang berada di luar dari kuadran A. Pihak manejemen organisasi/perusahaan dituntut untuk memberikan perhatian dan mengalokasikan sumber daya yang lebih pada faktor-faktor dalam kuadran ini.

2. Kuadran B - Pertahankan Kinerja (Keep Up The Good Work) Faktor-faktor yang terletak pada kuadran ini dinilai penting sebagai faktor penunjang kepuasan konsumen. Pada kuadran

72 M Gamble dan T. K. Gambel, Communicaton Works (Boston: McGraw-Hill Collage, 2002). 
ini pihak manajemen telah berhasil mengoptimalkan faktorfaktor yang ada dan dituntut untuk mempertahannya.

3. Kuadran C - Prioritas Rendah (Low Priority)

Faktor-faktor yang terletak pada kuadran ini berada pada level prioritas yang rendah. Pihak manajemen tidak perlu lebih memprioritaskan faktor-faktor pada kuadran ini dibandingkan dengan faktor-faktor lainnya.

4. Kuadran D - Berlebihan (Possible Overkill)

Faktor-faktor yang terletak pada kuadran ini dinilai tidak terlalu penting, sehingga pihak manajemen dirasa perlu untuk mengubah prioritasnya kepada faktor-faktor lain yang lebih penting.

Penelitian ini bertujuan untuk mengidentifikasi kepuasan konsumen akan pelayanan jasa laundry pada usaha Laundry XYZ melalui metode Importance Performance Analysis. Responden penelitian ini diambil dari seluruh konsumen Laundry XYZ pada bulan Agustus 2018.

Variabel penelitian ini mengacu pada variabel service quality yang digunakan pada penelitian para pakar terdahulu kemudian mengadopsinya dengan karakteristik usaha laundry. Untuk melakuan Importance Performance Analysis, maka diperlukan pengukuran variabel service quality yang mewakili tingkat harapan (importance) dan tingkat kinerja (performance). Subvariabel dalam penelitian ini adalah funtional quality dan technical quality yang diukur menggunakan skala Likert 5 poin. Untuk variabel service quality yang mewakili tingkat harapan (importance), skala pengukuran yaitu $1=$ sangat tidak penting, $2=$ tidak terlalu penting, $3=$ biasa saja, $4=$ penting $5=$ sangat penting. Variabel service quality yang mewakili tingkat kinerja 
(performance), skala pengukuran yaitu $1=$ sangat tidak setuju, $2=$ tidak terlalu setuju, 3 = biasa saja, $4=$ setuju $5=$ sangat setuju. Berikut ini adalah tabel operasional variabel penelitian. Berikut ini adalah definisi operasional variabel dan indikator service quality:

Tabel 1. Definisi Operasional Variabel dan Indikator Pertanyaan

Sub Definisi Indikator Pertanyaan

Sumbe Variabe operasiona

\begin{tabular}{|c|c|c|c|}
\hline $\begin{array}{l}\text { Funtion } \\
\text { al } \\
\text { quality }\end{array}$ & $\begin{array}{l}\text { Bagaimana } \\
\text { pelayanan } \\
\text { laundry } \\
\text { dilakukan } \\
\text { dengan } \\
\text { mempertim } \\
\text { bangkan } \\
\text { masalah- } \\
\text { masalah } \\
\text { perilaku } \\
\text { staf, } \\
\text { kontak } \\
\text { konsumen } \\
\text { dan } \\
\text { kecepatan } \\
\text { layanan. }\end{array}$ & $\begin{array}{l}\text { - Hasil layanan yang dipesan diserahkan } \\
\text { dengan baik oleh pihak Laundry XYZ. (X1) } \\
\text { - Setelah melihat hasil pekerjaan Laundry } \\
\text { XYZ, Anda merasa telah mendapat yang } \\
\text { Anda inginkan. (X2) } \\
\text { - Menggunakan jasa Laundry XYZ menurut } \\
\text { Anda adalah pengalaman yang bagus. (X3) } \\
\text { - Lamanya waktu tunggu layanan Anda } \\
\text { dikerjakan berada pada level yang bisa } \\
\text { diterima. (X4) } \\
\text { - Karyawan Laundry XYZ berupaya untuk } \\
\text { memangkas waktu tunggu untuk layanan } \\
\text { Anda segera dikerjaan. (X5) } \\
\text { - Pihak Laundry XYZ menjawab } \\
\text { pertanyaan-pertanyaan Anda dengan } \\
\text { cepat. (X6) }\end{array}$ & $\begin{array}{c}\text { Ali, } \\
\text { Faizan } \\
\text { et al. } \\
(2017)\end{array}$ \\
\hline $\begin{array}{l}\text { Technic } \\
\text { al } \\
\text { quality }\end{array}$ & $\begin{array}{l}\text { Apa yang } \\
\text { dirasakan } \\
\text { oleh } \\
\text { konsumen } \\
\text { Laundrryn } \\
\text { esia yang } \\
\text { berfokus } \\
\text { pada "apa" } \\
\text { dan } \\
\text { mengangga }\end{array}$ & $\begin{array}{l}\text { - Peralatan Laundry XYZ secara visual } \\
\text { adalah peralatan yang baik. (X7) } \\
\text { - Peralatan Laundry XYZ adalah peralatan } \\
\text { yang modern. (X8) } \\
\text { - Karyawan Laundry XYZ berpakaian dan } \\
\text { berpenampilan rapi. (X9) } \\
\text { - Lanudrynesia menyelesaikan pekerjaan } \\
\text { sesuai waktu yang dijanjikan. (X10) } \\
\text { - Saat ada masalah terhadap hasil } \\
\text { pelayanan Laundry, pihak Laundry XYZ }\end{array}$ & $\begin{array}{l}\text { Wang, } \\
\text { Yonggu } \\
\text { i et al. } \\
\text { (2004) }\end{array}$ \\
\hline
\end{tabular}




\begin{tabular}{|c|c|c|c|}
\hline $\begin{array}{c}\text { Sub } \\
\text { Variabe } \\
1\end{array}$ & $\begin{array}{c}\text { Definisi } \\
\text { operasiona } \\
1\end{array}$ & Indikator Pertanyaan & $\begin{array}{c}\text { Sumbe } \\
\mathrm{r}\end{array}$ \\
\hline & $\begin{array}{l}\text { p isu-isu } \\
\text { tersebut } \\
\text { sebagai } \\
\text { hasil akhir } \\
\text { dari } \\
\text { penyediaa } \\
\text { n layanan. }\end{array}$ & $\begin{array}{l}\text { menunjukkan ketulusan untuk } \\
\text { menyelesaikannya. (X11) } \\
\text { - Layanan yang Anda pesan dilaksanakan } \\
\text { dengan sebaik-baiknya. (X12) } \\
\text { - Karyawan Laundry XYZ selalu bersedia } \\
\text { membantu Anda. (X13) } \\
\text { - Karyawan Laundynesia tidak pernah } \\
\text { terlalu sibuk untuk menanggapi } \\
\text { permintaan saya. (X14) } \\
\text { - Karyawan Laundryneia tidak pernah } \\
\text { terlihat kesal untuk menanggapi } \\
\text { permintaan saya. (X15) } \\
\text { - Laundry XYZ memahami kebutuhan } \\
\text { spesial Anda tentang layanan yang } \\
\text { dipesan. (X16) } \\
\text { - Karyawan Laundry XYZ secara konsisten } \\
\text { berlaku sopan kepada Anda. (X17) } \\
\text { - Karyawan Laundry XYZ memberi } \\
\text { perhatian terhadap layanan Anda. (X18) } \\
\text { - Anda merasa aman mempercayakan } \\
\text { barang Anda kepada pihak Laundry XYZ. } \\
\text { (X19) } \\
\text { - Anda merasa barang yang Anda serahkan } \\
\text { kepihak Laundry XYZ tidak akan hilang } \\
\text { atau tertukar. (X20) } \\
\text { - Karyawan Laundry XYZ menanamkan } \\
\text { rasa kepercayaan kepada Anda. (X21) }\end{array}$ & \\
\hline
\end{tabular}

Kuesioner penelitian disebarkan kepada konsumen Laundry XYZ selama 3 bulan dari Juli, Agustus dan September 2018. Seluruh konsumen disyaratkan untuk mengisi kuesioner jika ingin mengambil barangmya, sehingga penelitian ini akan mengambil seluruh 
populasinya sebagai responden. Dalam penelitian ini akan dilakukan analisis validitas, reliabilitas dan analisis Importance Performance Analysis.

\section{Pembahasan}

Pada periode bulan Juli 2018 sampai dengan bulan September 2018, pengguna jasa Laundry XYZ mencapai 72 orang yang berbeda. Jumlah tersebut terdiri dari 41 orang laki-laki dan 31 orang perempuan. Layanan cuci kering setrika adalah produk layanan yang paling banyak diminati konsumen dengan jumlah pengguna layanan sebanyak 27 orang. Hal ini berbanding terbalik dengan jumlah pengguna layanan dry clean karpet yang cuma berjumlah 5 orang konsumen. Sisanya layanan laundry premium dan cuci kering biasa masing-masing memiliki jumlah pengguna layanan yang sama yaitu 20 orang konsumen. Berikut ini adalah tabel yang menggambarkan hal tersebut:

Tabel 2. Karakteristik Responden

\begin{tabular}{lcc}
\hline \multirow{2}{*}{ Jenis Kelamin } & Kategori & Jumlah \\
\cline { 2 - 3 } & Laki-laki & 41 orang \\
\hline \multirow{2}{*}{ Jumlah } & 31 orang \\
\hline \multirow{2}{*}{ Jenis Produk } & Cuci kering & 72 orang \\
\cline { 2 - 3 } & Cuci kering setrika & 20 orang \\
\cline { 2 - 3 } & Laundry premium & 20 orang \\
\cline { 2 - 3 } & Dry clean karpet & 5 orang \\
\hline & Jumlah & 72 orang \\
\hline
\end{tabular}


Jumlah responden sebanyak 72 orang mensyaratkan nilai hitung $\mathrm{r}$ product moment harus lebih tinggi dari 0,235. Nilai batas ini diperoleh melalui perhitungan degree of freedom sebesar 70 dari perhitungan $\mathrm{df}=\mathrm{N}$ (jumlah responden) $-2(\mathrm{df}=70-2)$ kemudian melihat tabel $\mathrm{r}$ product moment dengan nilai $\mathrm{df}=70$ pada tingkat signifikansi 5\%. Berdasarkan perhitungan seluruh atribut service quality yang mewakili tingkat harapan (importance) dan tingkat kinerja (performance) menunjukkan hasil yang valid, karena seluruh nilai hitung $\mathrm{r}$ product moment atribut-atribut tersebut berada di atas nilai 0,235 . Berikut adalah informasi lengkapnya:

Tabel 3. Validitas Instrumen Penelitian

\begin{tabular}{cccccc}
\hline \multirow{2}{*}{ No } & Item & \multicolumn{2}{c}{ Importance } & \multicolumn{2}{c}{ Performance } \\
\cline { 3 - 6 } & Pertanyaan & r hitung & Keterangan & r hitung & Keterangan \\
\hline 1 & X1 & 0,540 & valid & 0,534 & Valid \\
\hline 2 & X2 & 0,520 & valid & 0,462 & Valid \\
\hline 3 & X3 & 0,543 & valid & 0,439 & Valid \\
\hline 4 & X4 & 0,541 & valid & 0,443 & Valid \\
\hline 5 & X5 & 0,460 & valid & 0,463 & Valid \\
\hline 6 & X6 & 0,629 & valid & 0,534 & Valid \\
\hline 7 & X7 & 0,490 & valid & 0,530 & Valid \\
\hline 8 & X8 & 0,532 & valid & 0,419 & Valid \\
\hline 9 & X9 & 0,456 & valid & 0,534 & Valid \\
\hline 10 & X10 & 0,494 & valid & 0,475 & Valid \\
\hline 11 & X11 & 0,487 & valid & 0,599 & Valid
\end{tabular}




\begin{tabular}{llllll}
\hline 12 & X12 & 0,568 & Valid & 0,464 & Valid \\
\hline 13 & X13 & 0,585 & Valid & 0,563 & Valid \\
\hline 14 & X14 & 0,526 & Valid & 0,549 & Valid \\
\hline 15 & X15 & 0,444 & Valid & 0,527 & Valid \\
\hline 16 & X16 & 0,482 & Valid & 0,467 & Valid \\
\hline 17 & X17 & 0,526 & Valid & 0,567 & Valid \\
\hline 18 & X18 & 0,483 & Valid & 0,493 & Valid \\
\hline 19 & X19 & 0,489 & Valid & 0,477 & Valid \\
\hline 20 & X20 & 0,592 & Valid & 0,526 & Valid \\
\hline 21 & X21 & 0,609 & Valid & 0,614 & Valid \\
\hline
\end{tabular}

Seluruh item pertanyaan yang dinyatakan valid akan dilakukan uji reliabilitas. Uji ini mengukur kehandalan suatu variabel dalam kuesioner penelitian. Suatu variabel dikatakan reliabel jika memiliki Cronbach's Alpha lebih besar dari 0,60. Variabel service quality yang mewakili tingkat harapan (importance) dan tingkat kinerja (performance) pada penelitian ini termasuk dalam kategori reliabel karena nilai Cronbach's Alpha lebih besar dari 0,60. Tabel berikut ini merupakan hasil perhitungan reliabilitas instrumen penelitian.

Tabel 4. Reliabilitas Instrumen Penelitian

\begin{tabular}{ccc}
\hline Variabel & $\begin{array}{c}\text { Cronbach's } \\
\text { Alpha }\end{array}$ & Keterangan \\
\hline $\begin{array}{c}\text { Service Quality yang } \\
\text { mewakili tingkat harapan } \\
\text { (importance) }\end{array}$ & 0,841 & Reliabel \\
\hline
\end{tabular}


Service Quality yang

mewakili tingkat kinerja (performance)

0,769 Reliabel

\section{Pemetaan Importance Performance Analysis}

Untuk melakukan pemetaan Importance Performance Analysis, diperlukan nilai tengah untuk tiap-tiap atribut. Berikut adalah hasil perhitungan nilai tengah tiap atribut:

Tabel 5. Perhitungan Rata-Rata Atribut

\begin{tabular}{clcc}
\hline Kode & \multicolumn{1}{c}{ Atribut } & Importance & Performanace \\
\hline X1 & $\begin{array}{l}\text { Hasil layanan yang dipesan diserahkan } \\
\text { dengan baik oleh pihak Laundry XYZ. }\end{array}$ & 3,931 & 3,496 \\
\hline X2 & $\begin{array}{l}\text { Setelah melihat hasil pekerjaan Laundry } \\
\text { XYZ, Anda merasa telah mendapat yang } \\
\text { Anda inginkan. }\end{array}$ & 3,899 & 3,764 \\
\hline X3 & $\begin{array}{l}\text { Menggunakan jasa Laundry XYZ menurut } \\
\text { Anda adalah pengalaman yang bagus. }\end{array}$ & 3,764 & 3,681 \\
\hline X4 & $\begin{array}{l}\text { Lamanya waktu tunggu layanan Anda } \\
\text { dikerjakan berada pada level yang bisa } \\
\text { diterima. }\end{array}$ & 3,889 & 3,307 \\
\hline X5 & $\begin{array}{l}\text { Karyawan Laundry XYZ berupaya untuk } \\
\text { memangkas waktu tunggu untuk layanan } \\
\text { Anda segera dikerjaan. }\end{array}$ & 3,875 & 3,708 \\
\hline X6 & $\begin{array}{l}\text { Pihak Laundry XYZ menjawab } \\
\text { pertanyaan-pertanyaan Anda dengan } \\
\text { cepat. }\end{array}$ & 3,819 & 3,792 \\
\hline X7 & $\begin{array}{l}\text { Peralatan Laundry XYZ secara visual } \\
\text { adalah peralatan yang baik. }\end{array}$ & 3,889 \\
\hline X8 & $\begin{array}{l}\text { Peralatan Laundry XYZ adalah peralatan } \\
\text { yang modern. }\end{array}$ & 3,778 & 3,611 \\
\hline
\end{tabular}




\begin{tabular}{|c|c|c|c|}
\hline X9 & $\begin{array}{l}\text { Karyawan Laundry XYZ berpakaian dan } \\
\text { berpenampilan rapi. }\end{array}$ & 3,903 & 3,471 \\
\hline $\mathrm{X} 10$ & $\begin{array}{l}\text { Lanudrynesia menyelesaikan pekerjaan } \\
\text { sesuai waktu yang dijanjikan. }\end{array}$ & 4,097 & 3,806 \\
\hline $\mathrm{X} 11$ & $\begin{array}{l}\text { Saat ada masalah terhadap hasil } \\
\text { pelayanan Laundry, pihak Laundry XYZ } \\
\text { menunjukkan ketulusan untuk } \\
\text { menyelesaikannya. }\end{array}$ & 3,889 & 3,792 \\
\hline $\mathrm{X} 12$ & $\begin{array}{l}\text { Layanan yang Anda pesan dilaksanakan } \\
\text { dengan sebaik-baiknya. }\end{array}$ & 3,931 & 3,861 \\
\hline $\mathrm{X} 13$ & $\begin{array}{l}\text { Karyawan Laundry XYZ selalu bersedia } \\
\text { membantu Anda. }\end{array}$ & 3,931 & 3,357 \\
\hline $\mathrm{X} 14$ & $\begin{array}{l}\text { Karyawan Laundynesia tidak pernah } \\
\text { terlalu sibuk untuk menanggapi } \\
\text { permintaan saya. }\end{array}$ & 3,889 & 3,833 \\
\hline X15 & $\begin{array}{l}\text { Karyawan Laundryneia tidak pernah } \\
\text { terlihat kesal untuk menanggapi } \\
\text { permintaan saya. }\end{array}$ & 3,597 & 3,528 \\
\hline X16 & $\begin{array}{l}\text { Laundry XYZ memahami kebutuhan } \\
\text { spesial Anda tentang layanan yang } \\
\text { dipesan. }\end{array}$ & 3,764 & 3,360 \\
\hline $\mathrm{X} 17$ & $\begin{array}{l}\text { Karyawan Laundry XYZ secara konsisten } \\
\text { berlaku sopan kepada Anda. }\end{array}$ & 3,792 & 3,399 \\
\hline $\mathrm{X} 18$ & $\begin{array}{l}\text { Karyawan Laundry XYZ memberi } \\
\text { perhatian terhadap layanan Anda. }\end{array}$ & 3,819 & 3,667 \\
\hline X19 & $\begin{array}{l}\text { Anda merasa aman mempercayakan } \\
\text { barang Anda kepada pihak Laundry XYZ. }\end{array}$ & 3,875 & 3,764 \\
\hline X20 & $\begin{array}{l}\text { Anda merasa barang yang Anda serahkan } \\
\text { kepihak Laundry XYZ tidak akan hilang } \\
\text { atau tertukar. }\end{array}$ & 3,861 & 3,392 \\
\hline \multirow[t]{2}{*}{ X21 } & $\begin{array}{l}\text { Karyawan Laundry XYZ menanamkan } \\
\text { rasa kepercayaan kepada Anda. }\end{array}$ & 3,958 & 3,819 \\
\hline & Rata-Rata & 3,864 & 3,609 \\
\hline
\end{tabular}


Dari tabel di atas dapat dibuat diagram Importance Performance Analysis dengan membuat garis batas dari rata-rata nilai tingkat harapan (importance) dan tingkat kinerja (performance). Nilai tingkat kinerja (performance) merupakan sumbu $\mathrm{X}$, sedangkan nilai tingkat harapan (importance) merupakan sumbu Y. Berikut ini adalah hasil pemetaan Importance Performance Analysis pada Gambar 2.

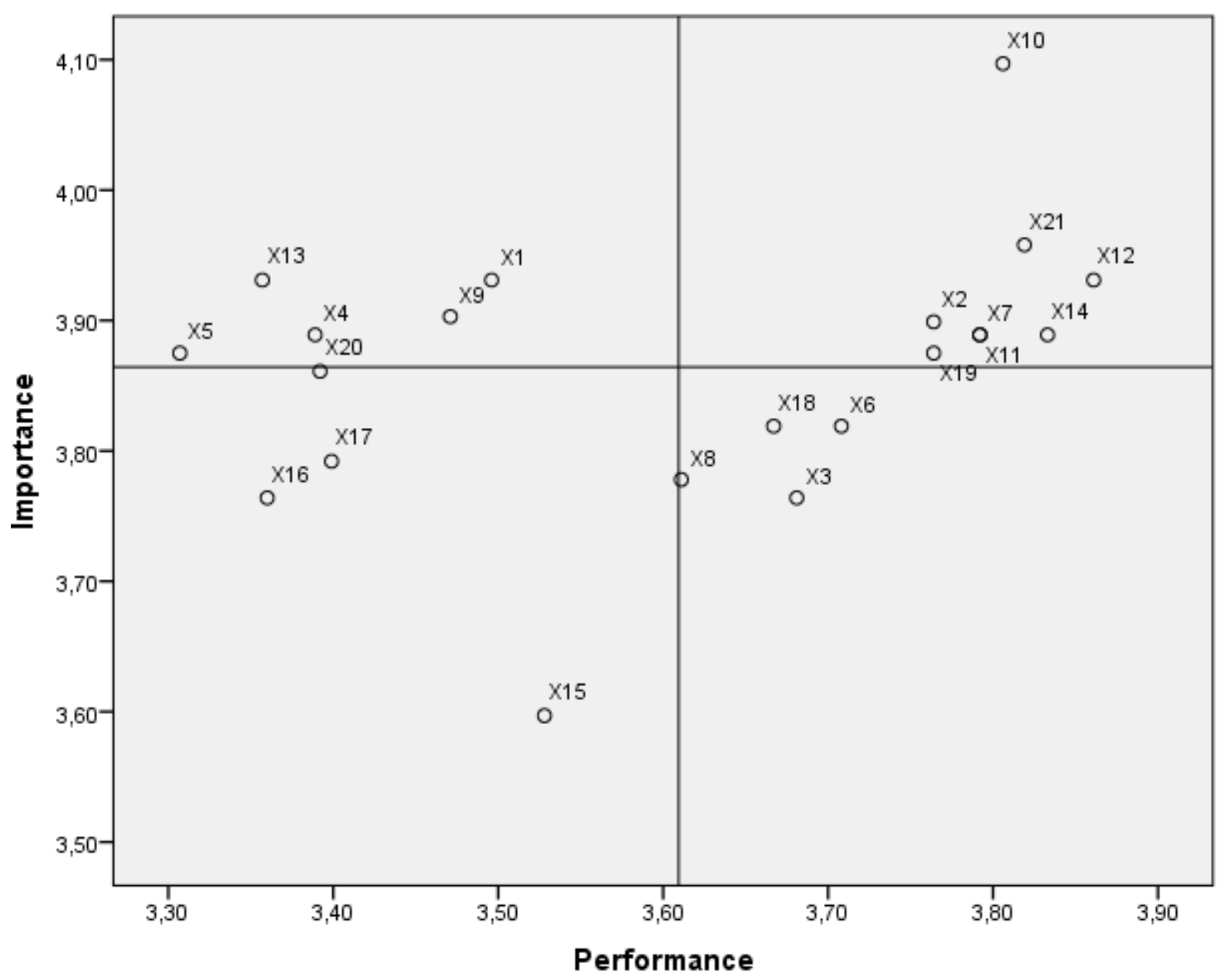

Gambar 2. Pemetaan Importance Performance Analysis

Berdasarkan gambar pemetaan Importance Performance Analysis di atas, dapat dikelompokkan atribut-atribut service quality dalam 4 (empat) kuadran seperti pada tabel berikut: 
Tabel 6. Perhitungan Rata-Rata Atribut

\begin{tabular}{|c|c|c|}
\hline Kuadran & Kode & Atribut \\
\hline \multirow{5}{*}{ A } & X1 & $\begin{array}{l}\text { Hasil layanan yang dipesan diserahkan dengan baik oleh } \\
\text { pihak Laundry XYZ. }\end{array}$ \\
\hline & $\mathrm{X} 4$ & $\begin{array}{l}\text { Lamanya waktu tunggu layanan Anda dikerjakan berada } \\
\text { pada level yang bisa diterima. }\end{array}$ \\
\hline & X5 & $\begin{array}{l}\text { Karyawan Laundry XYZ berupaya untuk memangkas waktu } \\
\text { tunggu untuk layanan Anda segera dikerjaan. }\end{array}$ \\
\hline & $\mathrm{X} 9$ & Karyawan Laundry XYZ berpakaian dan berpenampilan rapi. \\
\hline & $\mathrm{X} 13$ & Karyawan Laundry XYZ selalu bersedia membantu Anda. \\
\hline \multirow{8}{*}{ B } & $\mathrm{X} 2$ & $\begin{array}{l}\text { Setelah melihat hasil pekerjaan Laundry XYZ, Anda merasa } \\
\text { telah mendapat yang Anda inginkan. }\end{array}$ \\
\hline & $\mathrm{X} 7$ & $\begin{array}{l}\text { Peralatan Laundry XYZ secara visual adalah peralatan yang } \\
\text { baik. }\end{array}$ \\
\hline & $\mathrm{X} 10$ & $\begin{array}{l}\text { Lanudrynesia menyelesaikan pekerjaan sesuai waktu yang } \\
\text { dijanjikan. }\end{array}$ \\
\hline & X11 & $\begin{array}{l}\text { Saat ada masalah terhadap hasil pelayanan Laundry, pihak } \\
\text { Laundry XYZ menunjukkan ketulusan untuk } \\
\text { menyelesaikannya. }\end{array}$ \\
\hline & $\mathrm{X} 12$ & $\begin{array}{l}\text { Layanan yang Anda pesan dilaksanakan dengan sebaik- } \\
\text { baiknya. }\end{array}$ \\
\hline & X14 & $\begin{array}{l}\text { Karyawan Laundynesia tidak pernah terlalu sibuk untuk } \\
\text { menanggapi permintaan saya. }\end{array}$ \\
\hline & X19 & $\begin{array}{l}\text { Anda merasa aman mempercayakan barang Anda kepada } \\
\text { pihak Laundry XYZ. }\end{array}$ \\
\hline & X21 & $\begin{array}{l}\text { Karyawan Laundry XYZ menanamkan rasa kepercayaan } \\
\text { kepada Anda. }\end{array}$ \\
\hline & X15 & $\begin{array}{l}\text { Karyawan Laundryneia tidak pernah terlihat kesal untuk } \\
\text { menanggapi permintaan saya. }\end{array}$ \\
\hline & X16 & $\begin{array}{l}\text { Laundry XYZ memahami kebutuhan spesial Anda tentang } \\
\text { layanan yang dipesan. }\end{array}$ \\
\hline
\end{tabular}




\begin{tabular}{|c|c|c|}
\hline Kuadran & Kode & Atribut \\
\hline & $\mathrm{X} 17$ & $\begin{array}{l}\text { Karyawan Laundry XYZ secara konsisten berlaku sopan } \\
\text { kepada Anda. }\end{array}$ \\
\hline & $\mathrm{X} 20$ & $\begin{array}{l}\text { Anda merasa barang yang Anda serahkan kepihak Laundry } \\
\text { XYZ tidak akan hilang atau tertukar. }\end{array}$ \\
\hline \multirow{4}{*}{ D } & X3 & $\begin{array}{l}\text { Menggunakan jasa Laundry XYZ menurut Anda adalah } \\
\text { pengalaman yang bagus. }\end{array}$ \\
\hline & X6 & $\begin{array}{l}\text { Pihak Laundry XYZ menjawab pertanyaan-pertanyaan Anda } \\
\text { dengan cepat. }\end{array}$ \\
\hline & $\mathrm{X} 8$ & Peralatan Laundry XYZ adalah peralatan yang modern. \\
\hline & $\mathrm{X} 18$ & $\begin{array}{l}\text { Karyawan Laundry } \mathrm{XYZ} \text { memberi perhatian terhadap } \\
\text { layanan Anda. }\end{array}$ \\
\hline
\end{tabular}

Berdasarkan tabel di atas didapat hasil sebagai berikut:

1. Kuadran A - Prioritas Utama (Concentrate Here) pada atribut pelayanan X1, X4, X5, X9 dan X13.

2. Kuadran B - Pertahankan Kinerja (Keep Up The Good Work) pada atribut X11, X12, X14, X19 dan X21.

3. Kuadran C - Prioritas Rendah (Low Priority) pada atribut X15, X16, X17 dan X20.

4. Kuadran D - Berlebihan (Possible Overkill) pada atribut X3, X6, X8 dan X18.

\section{Simpulan}

Berdasarkan hasil perhitungan Importance Performance Analysis memprioritaskan pelayanan pada penyerahan yang baik barang milik konsumen, memangkas waktu tunggu pengerjaan layanan, meningkatkan kerapian penampilan karyawan dan berusaha menunjukkan usaha untuk membantu. 


\section{Daftar Pustaka}

Baker, Julie, dan Charles W. Lamb. "Measuring Architectural Design Service Quality." Journal of Professional Services Marketing 10, no. 1 (1994): 89-106.

Doelhadi, E. M., dan Agus Subekti. "Mengukur Tingkat Kepuasan Pelanggan: Perspektif Psikologi Konsumen." Fakultas Psikologi Universitas Airlangga 8, no. 1 (2006).

Gamble, M, dan T. K. Gambel. Communicaton Works. Boston: McGraw-Hill Collage, 2002.

Grönroos, Christian. "A Service Quality Model and Its Marketing Implications." European Journal of marketing 18, no. 4 (1984): 36-44.

Kotler, Philip. Manajemen Pemasaran. Edisi IX (terjemahan). Jilid II. Jakarta: Penerbit Erlangga, 1997.

Martilla, John A., dan John C. James. "Importance-performance analysis." The journal of marketing, 1977, 77-79.

Parasuraman, Anantharanthan, Valarie A. Zeithaml, dan Leonard L. Berry. "A conceptual model of service quality and its implications for future research." the Journal of Marketing 49, no. 4 (1985): 41-50.

Payne, Adrian, dan Adrian Payne. The essence of services marketing. USA: Prentice Hall, 1993.

Sunyoto, Danang. "Dasar-dasar manajemen pemasaran." Yogyakarta: Caps, 2012.

Tjiptono, F., dan C. Gregorius. "Service Quality \& Satisfaction, Yogyakarta: Penerbit ANDI.” Edisi III, 2011.

Wijaya, Tony. "Manajemen kualitas jasa." Jakarta: PT. Indeks, 2011. 